GLOBAL JOURNAL OF SOCIAL SCIENCES VOL 18, 2019: 1-10

COPYRIGHT@ BACHUDO SCIENCE CO. LTD PRINTED IN NIGERIA. ISSN 1596-6216

\title{
A CRITIQUE OF THE BUREAUCRATIC THEORY: THE NIGERIAN CIVIL SERVICE EXPERIENCE
}

\section{MORGAN, MORGAN OBONG, OKON, EMMANUEL EKPENYONG AND EMU, WINIFRED HARRY}

(Received 19 November 2018; Revision Accepted 23 January 2019)

\begin{abstract}
This paper presents a critique of the bureaucratic theory: The Nigerian Civil Service experience. The descriptive research approach was adopted for the study and the questionnaire instrument was used in data collection. Descriptive statistic was used in data analysis while multiple regression analysis was used in the test of hypotheses. It was discovered that hierarchical arrangement of staff significantly influence the Nigerian Civil Service and led to delays in decision making in the civil service. Further findings revealed that management by formal rule does not influences the Nigerian Civil Service. However, too many rules hinders employee's ability in response to turbulent environment. This situation make workers fixated and the bureaucratic nature of the civil service hardly creates room for change, hence high resistance to change. It was recommended that thorough and coherent reforms which will enshrine adequate institutionalization of Weberian ideal tenets of bureaucracy should be carried out in the civil service and attempt should be made to adopt the flat structure rather than the pinnacle hierarchical arrangement in order to enhance decision making and communication flow in the civil service.
\end{abstract}

KEYWORDS: Bureaucratic Theory; Nigerian Civil Service.

\section{INTRODUCTION}

Bureaucracy as a system of administration was projected to be the ideal and more efficient system of management in both public and private organizations/institutions. As an ideal model where emphasis is laid on rules, regulation, authority, officialdom and technical qualifications as the criteria for selection into both public and private organisations etc, the system was well articulated by a German Sociologist Max Webber to enhance efficiency through the application of clearly coin characteristic.

However, in recent times the inefficiency witness in most Nigerian ministries, parastatals and agencies has been attributed to the bureaucratic bottleneck in the civil service.
Bureaucracy is the bedrock of the public sector organizations; however, the bureaucracy of governmental institutions has become a burden and has made the civil service inefficient, hence staff performance. The inefficiency of most civil service organizations in Nigeria lead to the establishment of Service Compact with all Nigerians "SEVICOM" on the $21^{\text {st }}$ March 2004 during the administration of president Olusegun Obasanjo in an attempt to reduce the inefficiency in the civil service and as well enhance performance.

Bureaucracy in the Nigerian civil service has endured a considerable measure of difficulties because of its various issues. In the area of service delivery, numerous nationals have lost trust in bureaucratic establishment with

Morgan, Morgan Obong, Department of Business Management University of Calabar, Nigeria

Okon, Emmanuel Ekpenyong, Department of Business Management University of Calabar, Nigeria

Emu, Winifred Harry, Department of Educational Administration and Planning University of Calabar, Nigeria

(C) 2019 Bachudo Science Co. Ltd. This work is licensed under Creative Commons Attribution 4.0 International license. 
responsibilities of ensuring public services. However, Arnold (2014) emphasized that absolutely bureaucratic sort of administrative institutions is capable of attaining greater level of proficiency. The imperativeness of democracy depends on the ability of state institutions to deliver essential services and to resolves the problems that confront the society and this thus depends to a great extent on sincerity, competence, and inspiration of experts in the civil service (Gertrude, 2014).

Bureaucracy is a rational structure of coordinating human and material resources into a complex setting handled by professionals or experts (Agboola, 2016). Bureaucratic organisations are intended to be orderly, fair and very proficient. However, despite the beneficial aspect of bureaucracy in enhancing organizational efficiency, the civil service in Nigeria has some noteworthy negative reactions. A lot of red-tapism and paper work most times leads to unpleasant experience and ineffective operations. Also, since most workers depend to a large extent on rules and regulations, their flexibility, creativity and innovations suffers considerably in public service. Similarly, issues of rigidities, resistance to change, impersonality of relation and excess aloofness are often noticeable in public service bureaucracy. The way personnel are appointed into administrative positions is extremely politicized based on favoritism and tribalism. Personnel without adequate knowledge and credentials sometimes are designated into sensitive positions and this impact negatively on policies formulation and service delivery in the service.

However, this paper bridges the existing literature gap in the study of public service bureaucracy in Nigeria by presenting a critique of the bureaucratic theory of management from the civil service perspective, using a combination of variables such as the effect of hierarchical structure, rigidity of duties, management by formal rules and their implications on communication flow, decision making and workers initiative in the Nigerian civil service organizations. Furthermore, this paper is structured based on the following headings: Introduction, objective of the paper, statement of the problem, literature reviews (under appropriate headings), methodology, data analysis and test of hypotheses, findings, conclusion, recommendations, and implications of the study.

\section{STATEMENT OF THE PROBLEM}

Bureaucracy in Nigeria civil service is faced with many challenges that hamper its effective role in governance and development in the country. Bureaucracy is a form of administration that is based on rules and legitimate utilization of formal authority in organisations (Uwah, 2017). However, it is observably that bureaucracy in the Nigerian Civil Service is challenged by a number of issues such as rigidity of duties, lack of flexibility and creativity to respond to the dynamics of modern organizations. Also, tribalism, nepotism and favoritism in the recruitment and designation of personnel into sensitive administrative positions. This issues leads to poor policy formulations and implementation which give rise to abysmal service delivery, lack of accountability and corruption in the Nigerian Civil Service.

Furthermore, the pinnacle-like structure which interfaces with communication in the civil service and matters requiring urgent consideration are most times "swept under the carpet" as a result of the bureaucratic bottlenecks. Observably, this bottlenecks most times hinder the implementation of people oriented policies and programmes, since this polices must pass through the "pinnacle" for approvals. These issues promote impunity, corruption and nepotism in the service.

Similarly, monitoring and evaluation of performance of personnel in the federal civil service especially the placement of personnel in sensitive administrative position is a big challenge, Most times based on tribal and religious sentiment. This action promotes truancy and inefficiency in the civil service as most staff handles their work with levity, resuming late to work and leaving before official closing hours. Also, there are noticeable issues of god-fatherism in contract sharing by dubious personnel's in the service who represent the interest of their "godfathers" that influence their appointment into such sensitive position. These issues hinder the execution of contracts in the federal civil service. In view of these issues, it becomes timely to present a critique of the bureaucratic theory of management with particular reference to the Nigerian Civil service.

\section{OBJECTIVES OF THE PAPER}

The purpose of this paper is to present a critical 
analysis of the influence of bureaucracy

(hierarchical arrangement of staff, over rigidity of duties and management by formal rule) in the Nigerian Civil Service.

i. determine the effect of hierarchical arrangement staff in the Nigeria Civil Service.

ii. ascertain the effect of over rigidity of duties in the Nigeria Civil Service.

iii. examine the impact of management by formal rule in the Nigeria Civil Service.

\section{RESEARCH QUESTIONS}

i. To what extent does hierarchical arrangement of staff influence the Nigeria Civil Service

ii. To what extent does over rigidity of duties influence the Nigeria Civil Service

iii. To what extent does management by formal rule influence the Nigeria Civil Service

\section{RESEARCH HYPOTHESES}

$\mathrm{H}_{01}$ : Hierarchical arrangement of staff does not have significant influence in the Nigeria Civil Service

$\mathrm{H}_{02}$ : Over rigidity of duties does not have significant influence in the Nigeria Civil Service $\mathrm{H}_{03}$ : Management by formal rule does not have significant influence in the Nigeria Civil Service

\section{LITERATURE REVIEW CONCEPT OF BUREAUCRACY}

Observing organizations and being concern about its efficiency. The German sociologist Max Weber (1864-1920) developed an ideal model of bureaucratic theory of management as part of the total social theory which stressed on stringently defined hierarchy governed by rules and clearly delineated lines of authority (Inyang, 2004). He viewed a perfect organisation to be highly bureaucratized whose exercises and purposes are reasonably thought out and divisions of work unequivocally stated. Max Weber's theory of bureaucracy can be viewed as a way of accomplishing organisational effectiveness and proficiency in service delivery through effective leadership, order, division of work and specialization, chain of command, useful specificity, standards, directions and procedures (Alornyeku, 2011).

As indicated by Danjuma and Kamaruddin (2014) bureaucracy as a system of administration aims at enhancing efficiency in both public and private organizations based on clearly laid down rules, regulations and the legitimate use of formal authority. It is system where accentuation is placed on legitimate authority, knowledge and qualification as the basis for selection into public service. However, many public organisations such as the civil service both federal and states as well as other organisations today have profited from Weber's work. Division of work in organisation has been a crucial feature of an organisation structure. Dividing labour into clear specialize authority and obligations that are legitimized as official obligations helps to increase workers performance (Danjuma \& Philip, 2016).

Bureaucracy is necessary in civil service to characterize jobs and obligations. It encourages activities by ensuring that workers obligation is characterized clearly. Bureaucrat who are properly trained champions bureaucratic systems, and recruitment are based strictly on merit and qualifications, all of which affects the well functioning of activities within an organisation. However, the civil service bureaucracy with its attendant corruption and ethnicity has truncate this principle in most ministries, agencies and parastatals and lead to a situation where the wrong personnel are recruited based on favoritism to fill vacant position leading to poor performance (Kamaruddin, 2014).

The achievement of government relies to large extent on how public service bureaucracy functions. A productive and unbiased public bureaucracy is a basis for a sound democratic framework which is critical to efficient public bureaucracy (Mouzelis, 2015). Civil service bureaucracy has a critical part to play in the administration of the state, as it is endowed with public property. The important role of civil service in any country cannot be overemphasized, however, it is observed that a number of governmental laudable policies that would have contributed to the development of the country have been hampered by ineffective implementation of such policies. This situation has been attributed to the bureaucratic bottlenecks in the public service charged with the responsibility of implementing government policies.

\section{CHARACTERISTICS OF BUREAUCRACY}

As indicated by Juillerat (2010), Weber's theory of bureaucratic management has six essential characteristics. These characteristics include:

I. A formal hierarchical structure: This is a typical situation in the civil service where each level controls the level beneath and is controlled 
by the level above. A formal order is the premise of centralized planning and decision making. In this situation, workers know whom to answer to and who reports to them. The essential component of bureaucratic institutions is that there is a chain of command based on the hierarchy of authorities. Hierarchy is an arrangement of positioning different positions of an institution in a hierarchy from top to bottom (Juillerat, 2010). In the civil service bureaucracy, offices follow the tenet of hierarchy where the lower office is liable to control and supervision by a higher office. In this manner, no office is left uncontrolled in the institution. This hierarchy serves as lines of communication and assignment of authority. It infers that communication descending or going up must go through each position and this in most case distorts communication flow in the civil service.

II. Organization by functional specialty: In this situation task is to be carried by experts and personnel's are being organized into units based on their specialty or ability to perform a particular task; though the civil service bureaucracy have hampered this function given rise to a situation where "juicy" jobs are assigned to workers based on impunity, ethnicity and favoritism. This situation has also contributed to the poor performance of the civil service in Nigeria (Gertrude, 2014).

III. Management by rules: Managing by rules enables decision reach at the highest organizational hierarchy to be carried out by all levels of authority. In this case, civil service administrators established a well articulated system of rules, standard and norms to adequately control employees conduct in the organisation (Juillerat, 2010). A fundamental and most stressed characteristic of bureaucratic institution is that regulatory procedure is persistent and governed by official guidelines. A cogent way to deal with institutions requires an arrangement of a system of keeping up with the tenets of guaranteeing uniformity and coordination of efforts by employees in an institution. Rules offer the advantages of stability, strength, coherence, and consistency as all employees understands exactly the result of their behaviour in a specific issue (Mouzelis, 2015). However, this rigidity of rule hampers workers initiative and their ability to respond to turbulent environment.

IV. Employment based on technical qualifications: This is a procedure by which personnel's are selected into an organisation based on requisite skills and academic credentials to enhance the accomplishment of organisational goals (Juillerat, 2010). In this situation task are to be executed by experts and employees are organized into departments based on the kind of work they do or abilities they have. However, the civil service bureaucracy most times do not follow this principle in their recruitment, rather most recruitment are carried out based on ethnicity, favoritism and this has lead to recruitment of personnel without requisite qualifications and skills, thereby hampering the efficiency in the service.

V. Impersonality of relation: In the civil service there is high level of officialdom, where all activities are carried out officially devoid of informal grouping in the system. Though in Nigeria, the Nigeria Labour Union has made significant impact in encouraging union activities in the civil service in order for continuous demand in workers remuneration (Agboola, 2016).

VI. Regular duties assigned to individuals as fixed duties: Activities are assigned to various individual in the system. Here official positions are free from individual involvement, emotions and sentiments (Inyang, 2004).

\section{CRITICISMS OF BUREAUCRACY}

From his own point of view, Weber knew about the presumable dysfunctionality related with his bureaucratic model and anticipated the following: conflicting interest of bureaucrats; nepotism and abuse of bureaucratic powers; corruption and different kinds of abuses; political infighting and assignments of positions and assets (Alornyeku, 2011). In fact excessive bureaucracy harmfully influences social and economic advancement particularly in developing country like Nigeria. As indicated by Aule and Odo (2015) excessive bureaucracy hinders the performance of public service and impact significantly on the achievement of government objectives of establishing such institutions. Such bureaucratic institutions are characterized by red-tapism, paper work, impersonality of relations and rules among others.

Bureaucracy can be found in a number of large organisations, especially in the civil service. As indicated by Johnston (2011) bureaucracy is the most expanded arrangement of rules and regulations which is used in a wide range of organisations, particularly in the civil service. However, exorbitant adherence to rules and regulations will definitely bring about deviations of objectives, create bottleneck and stifle workers initiative. 
According to Arnold (2014), bureaucratic systems are moderate at pace and result in delays in decision making due to hierarchy of authority and rules, which sometimes hinders innovation and flexibility in organisation. Since most official duties in the civil service are carried out in written form, and approvals are given based on hierarchy of authority. This leads to time wastage and other administrative challenges due to high level of red-tapism which impact negatively on performance (Charles, 2011). Moreover, Weber's bureaucracy did not consider the significant role of the informal relationship that exists in any institution (Inyang, 2004).

\section{REVIEW OF EMPIRICAL LITERATURE}

Few studies in Nigeria have attempted to establish a relationship between bureaucracy and the public service. These situations leave a gap in the literature. However, Uwah (2017) examined the effect of bureaucracy on management in public institutions. The study employed the survey research design. The population of the study was 6241 and simple random sampling technique was used for the study. Taro Yamene formula was used in determining a sample size for the study which gave a total number of 376 . The simple linear regression analysis was used in test of hypotheses. The study found that specialization of task, employment on qualification and management by rules has significant effect on communication flow, performance and attainment of goals in public institutions.

Similarly, Mouzelis (2015) investigated the relationship between bureaucratic tenets and service delivery in Malaysian public sector. Descriptive research design was adopted for the study. Data for the study was sourced primarily using the questionnaire. The study population was 700 and simple random sampling technique was adopted for the study. Correlation analysis was used in testing hypotheses. The outcome of the study revealed that bureaucratic tenets have significant relationship with service delivery in Malaysian public sector. Also, it was found that hierarchy of authority in the public sector interferes with communication flow and over rigidity of rules stifles workers innovativeness.

Furthermore, study carried out by Charles (2011) on the influence of bureaucracy on the effectiveness of Corporations in Jordan. It was found that management by formal rule hinders decision making and employee's ability to response to turbulent environment. Further finding from the study showed that there is no significant relationship between bureaucratic principles and workers innovations in the organisation.

Aule and Odo (2015) studied the effect of over rigidity of rules in public organisations in Ondo State, Nigeria. The survey research design was used for the study. Questionnaire instrument was use in obtaining primary data for the study. The population of the study was 350 respondents. Applying descriptive statistics on the data collected, the study revealed that over rigidity of rules in Ondo State civil service hinders workers initiative and their performance.

Similarly, Ayodele (2015) investigated the effect of bureaucracy in public organizations in Lagos State. The research employed the survey research design and a population of 380 employees selected from 15 public organisations in Lagos State. Regression analysis was adopted for data analysis and test of hypotheses. The study found that bureaucratic inefficiency in Lagos public organisations is rooted in the element of its disparity with the ideal kind of Weberian bureaucracy where offices are not filled on merit, but on basis of other extraneous conditions such as ethnicity, favoritism and religious inclination among others, this leads to a situation where the wrong candidates are recruited and assigned task that are meant for professionals.

Murhammed and Nasir (2014) carried out a study to determine the effect of bureaucracy on coordination in the civil service in Kaduna State. The study adopted the survey research design. Questionnaire was used for data collection. The sample size for the study was 400 selected from Kaduna public service. Chi-Square statistical technique was used for data analysis and test of hypotheses. The study found that specialization and assignment of task in Kaduna State civil service increase the challenge of lack of coordination. Also, it was found that failure to recognize the importance of informal relations that exist in public organisations in Kaduna lead to a tense relationship between the government and labour unions in the state.

Furthermore, Abdulkareem and Gabadeen (2015) investigated the relationship between bureaucracy and workers performance in public sector in Nigeria. The study adopted the survey research method. Twenty five public organisations were selected for the study with a combined population of 327. Questionnaire instrument was used for data collection. Data obtained for the study were analyzed with the aid 
of regression analysis. The study found that there is no relationship between rigidity of rules, hierarchy of authority and impersonality of relation on workers performance in the selected public organizations in Nigeria. The study concluded that effective application of Webber's bureaucratic principles could enhance efficiency and quality of personnel's recruited into the public service.

Similarly, Danjuma and Kamaruddin (2014) conducted a study on the implications of effective application of bureaucracy in public organisations in Nigeria. The study adopted the survey research design. Purposive sampling technique was applied to select the required sampled respondents. Ten public organizations were selected for the study with a population of 260. Questionnaire instrument was used in eliciting data for the study. Pearson Product Moment Correlation technique was used in test of hypotheses, the study found that specialization of task, recruitment of workers based on credentials and standard rules have significant effect in public organisations in Nigeria.

\section{METHODOLOGY}

This paper employed a descriptive research approach to critically evaluate the bureaucratic theory in the Nigerian civil service using questionnaire in the collection of data. Furthermore, the descriptive approach adopted in this paper provides a better understanding of the problems and implications associated with bureaucracy in the Nigerian civil service by exploring the research topic with varying levels of depth through review of literatures with a view to uncovering facts.

\section{STUDY SETTING/POPULATION OF THE STUDY}

The study setting was the Federal Secretariat Complex in Calabar, Cross River State. The population of the study was two hundred (200) federal civil servants spread across five Federal Ministries in Cross River State. The Federal ministries included in the study were the federal ministry of Finance, Agriculture, Labour and Employment, Power, Works and Housing and Commerce and Industries. However, a census of the entire population of the five randomly selected Federal Ministries in Calabar, Cross River State was used for the study. Two hundred copies of questionnaire was administered to respondents in the sample federal ministry personally by the researcher. However, the entire 200 copies was returned and used for the study, representing 100 percent return rate.

\section{METHOD OF DATA ANALYSIS}

The paper employed the descriptive statistics to evaluate the variables based on the values of standard deviation and mean and ascertained the significance level of the variables utilized in the study. Multiple regression analysis was employed to test the hypotheses developed for the study to critically evaluate the influence of bureaucracy in the Nigerian civil service. The multiple regression model was specified as shown below:

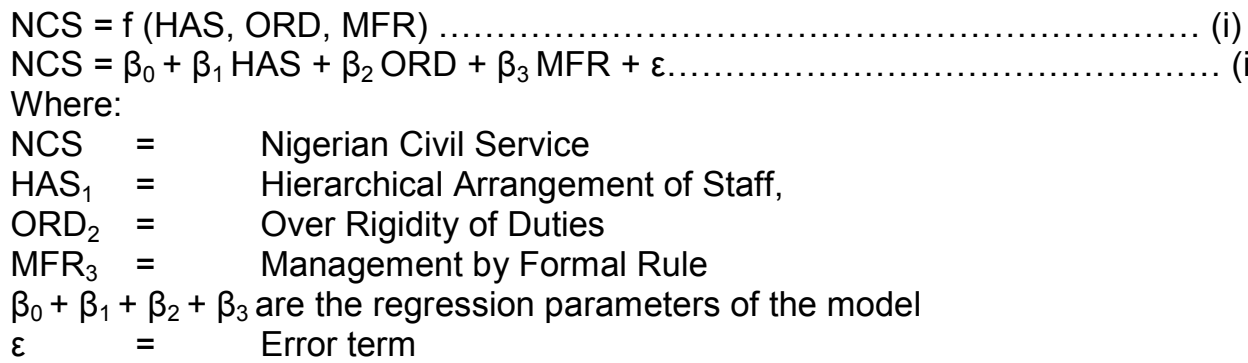

Where:

NCS = Nigerian Civil Service

$\mathrm{HAS}_{1}=$ Hierarchical Arrangement of Staff,

$\mathrm{ORD}_{2}=\quad$ Over Rigidity of Duties

$\mathrm{MFR}_{3}=$ Management by Formal Rule

$\beta_{0}+\beta_{1}+\beta_{2}+\beta_{3}$ are the regression parameters of the model

$\varepsilon=$ Error term

\section{DATA ANALYSIS AND RESULT}

Table 1 below shows the descriptive statistics of three bureaucratic variables: hierarchical arrangement of staff, over rigidity of duties and management by formal rule. Based on the table, hierarchical arrangement of staff has the highest mean and standard deviation with values of 4.09 and 0.75 respectively with corresponding high significance level indicating that hierarchical arrangement of staff highly correlates with the Nigerian Civil Service. This was followed by management by formal rule with mean and standard deviation values of 4.02 and 0.73 with corresponding high significance level, while over rigidity of duties has the lowest mean and standard deviation with values of 3.97 and 0.73 with corresponding moderate significance 
level. The aggregate mean and standard deviation was 4.00 and 0.61 respectively indicating that the three bureaucratic variables used for the study correlates with the Nigerian Civil Service.

Table 1:Descriptive statistics of bureaucracy variables used for the study

\begin{tabular}{|c|c|c|c|c|}
\hline Bureaucracy & $\mathrm{N}$ & Mean & Std & $\begin{array}{l}\text { Significance } \\
\text { level. }\end{array}$ \\
\hline $\begin{array}{l}\text { Hierarchical } \\
\text { arrangement of staff }\end{array}$ & 200 & 4.09 & 0.75 & High \\
\hline $\begin{array}{l}\text { Over rigidity of } \\
\text { duties }\end{array}$ & 200 & 3.97 & 0.69 & Moderate \\
\hline $\begin{array}{l}\text { Management by } \\
\text { formal rule }\end{array}$ & 200 & 4.02 & 0.73 & High \\
\hline $\begin{array}{l}\text { Aggregate mean } \\
\text { and Std }\end{array}$ & & 4.00 & 0.61 & \\
\hline
\end{tabular}

Source: Fieldwork, 2018

Table 2: Regression result of influence of bureaucracy and Nigerian Civil Service

\begin{tabular}{lllllll}
\hline Model & \multicolumn{5}{c}{ Coefficients $^{\text {a }}$} \\
& & \multicolumn{2}{l}{ Unstandardized Coefficients } & $\begin{array}{l}\text { Standardized } \\
\text { Coefficients } \\
\text { Beta }\end{array}$ & $\mathrm{t}$ & Sig. \\
\hline & B & Std. Error & . & 4.781 & .000 \\
1 & (Constant) & 3.597 & .752 & 1.311 & 3.288 & .001 \\
& HAS & 1.015 & .309 & .043 & .972 & .332 \\
ORD & .066 & .068 & -.426 & -1.088 & .278 \\
\hline
\end{tabular}

Table 3: Anova $^{a}$

\begin{tabular}{lllllll}
\hline Model & & Sum of Squares & $\mathrm{df}$ & Mean Square & $\mathrm{F}$ & Sig. \\
\hline & Regression & 1235.793 & 3 & 411.931 & 356.167 & $.000^{\mathrm{b}}$ \\
& Residual & 226.687 & 196 & 1.157 & & \\
1 & Total & 1462.480 & 199 & & & \\
\hline
\end{tabular}

Table 4: Model Summary

\begin{tabular}{llllll}
\hline Model & $\mathrm{R}$ & $\mathrm{R}$ Square & $\begin{array}{l}\text { Adjusted } \mathrm{R} \\
\text { Square }\end{array}$ & $\begin{array}{l}\text { Std. Error of the Durbin-Watson } \\
\text { Estimate }\end{array}$ \\
\hline 1 & $.919^{\mathrm{a}}$ & .845 & .843 & 1.077 & 2.081 \\
\hline
\end{tabular}

a. Dependent Variable: NCS

b. Predictors: (Constant), MFR, HAS, ORD

@ $\mathrm{P}<0.05$

$\mathrm{N} \mathrm{CS}=3.597+1.015(\mathrm{HAS})+0.066(\mathrm{ORD})+-.333$ (MFR).

$S$ td. Error $=$ [0. .752], [0. .309], [0. .068] and [0. .306].

t-statistic $=[4.781],[3.288],[0.972]$ and $[-1.088]$.

Source: SPSS output (2018)

\section{TEST OF HYPOTHESES}

$\mathrm{H}_{01}$ : Hierarchical arrangement of staff does not have significant influence in the Nigeria Civil Service.
$\mathrm{Hi}_{1}$ : Hierarchical arrangement of staff have significant influence in the Nigeria Civil Service. $\mathrm{H}_{02}$ : Over rigidity of duties does not have significant influence in the Nigeria Civil Service. 
$\mathrm{Hi}_{2}$ : Over rigidity of duties have significant influence in the Nigeria Civil Service.

$\mathrm{H}_{03}$ : Management by formal rule does not have significant influence in the Nigeria Civil Service

$\mathrm{Hi}_{3}$ : Management by formal rule have significant influence in the Nigeria Civil Service

Table 2 shows multiple regression result of influence of bureaucracy (Hierarchical Arrangement of Staff (HAS), Over Rigidity of Duties (ORD) and Management by Formal Rule (MFR) in the Nigerian Civil Service (NCS). The table indicates that hierarchical arrangement of staff has a beta coefficient value of 1.311 with a significant value of 0.001 which is less than $p<0.05$ level of significance, hence hierarchical arrangement of staff significantly influence the Nigerian Civil Service. Over rigidity of duties has a beta coefficient value of 0.043 with a probability value of 0.332 which is greater than $P<0.05$, level of significance, hence over rigidity of duties does not significantly influence the Nigerian Civil Service. Management by formal rule has a beta coefficient value of -0.426 with a probability value of 0.332 which is greater than $P<0.05$ level of significance, hence management by formal rule does not significantly influence the Nigerian Civil Service.

The coefficient of multiple determination as indicated by the Adjusted R-square value of 0.843 showed that the regressands variables were able to explain 84.3 percent variations in the Nigerian Civil Service, while the model did not explain the remaining 15.7 percent.

The overall significance of the model carried out through the ANOVA F-test showed a value of 356.167 which was found to be statistically significant at $P<0.05(P=000)$ level of significance, thus ascertaining the validity of the model. The Durbin-Watson statistic which is a measure of autocorrelation has a value of 2.081 which shows that the model was free from positive or negative autocorrelation. Based on the regression result, alternative hypotheses $\mathrm{H}_{\mathrm{i}}$ was accepted in hypotheses 1 since the significance value of .001 was less than the $P<0.05$ level of significance, while the null hypotheses was accepted in hypotheses 2 and 3 since the significance values of .332 and .278 were higher than the $P<0.05$ level of significance. This implies that hierarchical arrangement of staff significantly influence the Nigerian Civil Service, while over rigidity of duties and management by formal rules does not statistically influence the Nigerian Civil Service. This finding was corroborated by the finding of Danjuma and Kamaruddin (2014) who found that arrangement of staff based on hierarchy, specialization of task, recruitment of workers based on credentials and standard rules have significant effect in public organizations in Nigeria.

\section{SUMMARY OF FINDINGS}

The paper presents a critique of the bureaucratic theory: The Nigerian Civil Service experience. Based on test of hypotheses, the paper found that:

Hierarchical arrangement of staff significantly influence the Nigerian civil service and leads to delays in decision making. Also, bureaucratic inefficiency in the Nigerian civil service was found to be rooted in the element of its variation with the ideal type of Weberian bureaucracy; where most offices are not filled on merit, but on other conditions, such as ethnicity, favoritism and religious inclination among others, this leads to a situation where the wrong candidates are recruited and assigned task that are meant for professionals. This situation perverts the Weberian bureaucratic edifice.

Over rigidity of duties does not significantly influence the Nigerian Civil Service. Over rigidity of duties leads to over specialization and make performance of duties outside the schedule impossible and very challenging. This lead to a situation where workers innovativeness are stifle, as a result several reforms have been carried out with the aim of enhancing workers efficiency and one of such reforms lead to the establishment of SEVICOM in an attempt to enhance workers productivity in the civil service.

Management by formal rule does not influences the Nigerian Civil Service. However, too many rules hinders employee's ability to response to turbulent environment. This situation make workers fixated and the bureaucracy in the civil service hardly create room for change and brings about high resistance to change.

\section{CONCLUSION}

It can be concluded that bureaucracy as a system of administration aim at enhancing efficiency in organizations based on clearly laid down rules, regulations and the legitimate use of formal authority. However adherence to basic bureaucratic tenets such as formal structure and administration by rules, merit based recruitment on skills and qualifications and hierarchy of authority could lead to improved efficiency. Therefore, public service bureaucracy in Nigeria should pay attention to the basic tenets of 
bureaucracy in order to enhance service delivery while eradicating negative bureaucratic tendency and allows for workers flexibility in the ever increasing dynamic work environment for improved service delivery in the Nigerian public service.

\section{RECOMMENDATIONS}

Based on the findings from this paper, there is need to establish sound and effective public bureaucracy in Nigeria. To this end, bureaucratic ineffectiveness has to be eliminated in the Nigeria public service. Furthermore, the following recommendations were made:

i. The civil service in Nigeria should make effort at adopting the flat structure rather than the pinnacle-like hierarchical arrangement, in order to enhance decision making and communication flow in the system. Also, well articulated reforms which will enshrine proper institutionalization of Weberian ideal tenets of bureaucracy should be carried out as well as proper implementation of the SEVICOM objectives in ministries, parastatals and agencies in order to enhance efficiency of the civil service.

ii. Recruitment into public service should be based on merit as well as qualification while eradicating favoritism, ethnicity and religious sentiments in public service recruitment to improve the quality of workers recruited into the service and efficiency of public service.

iii. Though regulations are essential to guide the activities of staff in the civil service, there is no organisation that could made rules for all employees activities, as such rules should be flexible in the public service and allows for workers initiative in response to changes in the environment. Also, government should provide incentives for bureaucrats who adheres to ideal bureaucratic tenets in the civil service

\section{IMPLICATIONS OF THE STUDY}

This paper will have significant theoretical implications for academics, as it will contribute to the body of literature on the implications of bureaucracy in the civil service. Also, the paper will enhance effective organisation of the contemporary workplace through the implementations of the ideal bureaucratic principles. Furthermore, this paper will have theoretical implications to students by providing a framework for explanation and interpretation of facts about bureaucracy and enhance their further investigations into the implication of bureaucracy in civil service.

Also, the paper will have practical implications in the civil service and other organizations as it will enhance comprehensive and well articulated reforms which will facilitate the institutionalization of Weberian tenets of bureaucracy in organizations and enhance workers efficiency. Also, the paper will enable heads of ministries, parastatals and agencies to adopt appropriate structures which will enhance communication flow in the civil service.

Furthermore, the paper will have significant managerial implications which will enable managers establish sound and efficient bureaucracy while eradicating bureaucratic inefficiency in their organizations, hence enhance workers efficiency. Also, this paper will enable managers to establish flexible rules in their organizations which could allow for employees initiative and enable them to response to changes in the environment.

\section{REFERENCES}

Abdulkareem, A., and Gabadeen O., 2015. Investigation of the relationship between bureaucracy and workers performance in public sector in Nigeria. Public Policy and Administrative Research, 5 (12), 22-29.

Agboola, T. O., 2016. Bureaucratic politics and policy development: Issues and challenges. African Journal of International Relations, 10 (2), 11-19.

Alornyeku L., 2011. Rethinking public services in Nigeria. Ibadan: Carligate Publishing Company Limited.

Arnold O., 2014. Bureaucracy everywhere $\left(2^{\text {nd }}\right.$ Ed.). London: McGraw Hill.

Aule, O., and Odo U., 2015. The effect of over rigidity of rules in public organisations in Ondo State. Review of Public Administration and Management, 4 (8), 41-50.

Ayodele T., 2015. The implication of bureaucracy in public organization in Lagos State. 
International Journal of Management, 4(3), 105-117.

Charles H., 2011. The effect of bureaucracy on the performance of Jordanian Multinational Corporations. Jordanian Journal of Business, 34(6), 102-119.

Danjuma, B., and Philip A., 2016. Bureaucracy and development in Nigeria: Issues and perspectives. Journal of Developing Country Studies, 1(2), 1-11.

Danjuma, H. and Kamaruddin O., 2014. The implications of effective application of bureaucracy in public organisations in Nigeria. Journal of Developing Country Studies, 3 (2), 32-41.

Gertrude, S., 2014. Bureaucracy and corruption in Ugandan public service. International Journal of Public Policy, 6 (8), 159-169.

Inyang, B. J., 2004. Management theory: Principles and practice $\left(2^{\text {nd }} E d\right)$. Calabar: Merb Publishers.

Johnston, K., 2011. Busting bureaucracy. Retrieved from://www.bustingbureaucracy.com/excerpts/theorg.html.
Juillerat, S. 2010. How does bureaucracy affect public service? Retrieved from www.publicbureaucracy.org/t447ryu/436 47.pdf/tyd67

Kamaruddin, S., 2014. Implications of bureaucracy and rural development: The Nigerian perspective. Global Journal of Management and Business, 12 (4), 1840.

Mouzelis, R., 2015. Implication of bureaucratic principles in modern organization in Malaysia. International Journal of Management, 32 (14), 56-73.

Murhammed, A., and Nasir, O., 2014. The effect of bureaucracy on coordination in civil service in Kaduna State. Journal of Business and Management, 6 (4), 171192.

Uwah, K., 2017. Implications of bureaucracy on management of University of Calabar, Cross River State, Nigeria. Unpublished M.Sc Thesis Department of Business Management, University of Calabar, Calabar. 